\title{
At-Turats
}

Jurnal Pemikiran Pendidikan Islam

journal homepage: http://jurnaliainpontianak.or.id/index.php/atturats

\section{THE MATERIAL OF WAWASAN NUSANTARA AS INDONESIAN GEOPOLITIC NOTE AND THE IMPLEMENTATION IN ISLAMIC STATE UNIVERSITY Arief Adi Purwoko ${ }^{1}$ \\ Islamic State Institute of Pontianak \\ ariefadipurwoko@iainptk.ac.id}

\begin{abstract}
Abstrak: Arus globalisasi menggerus arti negara dalam bentuk kewilayahan, atau dalam perspektif geografi dalam hal batas-batasnya (borderless). Kehadiran krisis sebagaimana pandemi Covid-19 hadir untuk mengingatkan kembali keberadaannya. Batas, kedaulatan, dan kekuatan dari sebuah negara, yang secara nyata berhadapan dengan kepentingan politik dunia. Geopolitik telah lama menjadi kajian penting bagi penguatan kemampuan sebuah bangsa untuk bertahan di tengah hegemoni. Sebagaimana Indonesia dengan gigih mempertahankan Deklarasi Djuanda 1957 sebagai nota geopolitik tertulis, yang akhirnya berhasil mempengaruhi hukum laut internasional dan meneguhkan asas negara kepulauan (archipelago state). Sedemikian pentingnya materi geopolitik tersebut seharusnya memiliki andil dalam penguatan ketahanan nasional (national resillience), khususnya strategi pertahanan nasional (national defence). Pendidikan Tinggi Keagamaan Islam Negeri (PTKIN) merupakan media strategis untuk menransformasikan geopolitik terhadap kemampuan warga negara, sebagaimana diketahui Islam merupakan agama terbesar yang dianut oleh rakyat Indonesia, sekaligus memiliki pengaruh krusial bagi ideologi bangsa. Artikel ini mencoba untuk menguak peran pendidikan kewarganegaraan, terutama pada materi wawasan nusantara (national outlook) sebagai nota geopolitik warga negara. Penelitian dalam artikel ini bersifat kualitatif dengan menggunakan model penelitian literatur. Pandangan yang dapat diajukan dalam artikel ini diantaranya antara lain: aspek ideologis geopolitik warga negara seringkali melibatkan nilai-nilai primordial sehingga keutuhan cara pandang terhadapnya menjadi terganggu. Peran lokalisme dan Islam sebagai pembentuk aspek ideologi geopolitik, seharusnya dapat dikemas dengan baik sebagai pengikat identitas bangsa. Dalam hal ini, PTKIN sebagai lembaga pendidikan tinggi yang bercorak khas keislaman, seharusnya mampu menerjemahkan nilai universalitas moral good dalam Islam kepada rasa persatuan umat yang beridentitas kebangsaan. Adapun untuk menuju hal tersebut, PTKIN harus mampu meramu suatu materi terintegratif antara nilai Islam sebagai aras epistemologis ideologi Pancasila dan doktrin pertahanan nasional nirmiliter. Bagaimanapun juga peserta didik di PTKIN adalah sumber daya strategis pertahanan nasional nirmiliter, terutama dalam pembangunan karakter bangsa di tengah masyarakat.
\end{abstract}

Kata Kunci : Wawasan Nusantara, Geopolitik, Pendidikan Tinggi Keagamaan Islam Negeri

\footnotetext{
${ }^{1}$ Staf Pengajar Bidang Keahlian Kewarganegaraan di Institut Agama Islam Negeri Pontianak
} 


\section{A. Pendahuluan}

Hadirnya narasi novel coronavirus (nCov-19) pada penghujung tahun 2019 menjadi mimpi buruk bagi peradaban manusia. Tidak hanya melibatkan Republik Rakyat Tiongkok (RRT), di mana Wuhan disebut-sebut sebagai ruang kemunculan virus, kemudian dengan sangat cepat telah merambat dan berkembang menjadi isu paling krusial di seluruh belahan dunia. Virus yang selanjutnya menjadi penyebab pandemi dan oleh World Health Organization (WHO) disebut sebagai coronavirus desease (Covid-19), dalam perspektif tertentu juga telah beranjak menjangkiti isu-isu yang berkaitan dengan geopolitik. Dapat dipahami demikian, dapat ditelisik dari prediksi tentang kemunculan kebudayaan baru dengan sebutan "new normal", hingga melibatkan ranah yang lebih sensitif, yakni tentang isu keamanan dan pertahanan nasional di berbagai negara.

Hingga Mei 2020 Covid-19 telah hampir merenggut setengah juta jiwa penduduk dunia. Tidak hanya terhenti pada pembahasan tersebut, potensi katastropik virus juga telah merambati lambung maupun jantung peradaban melalui berbagai krisis berkepanjangan yang diakibatkan oleh ambivalensi destruktif atas penanganan terhadapnya, sebagaimana terjadinya krisis ekonomi yang disebabkan oleh kebijakan lockdown, atau krisis hubungan internasional maupun potensi atas kebangkitan hantu perang dingin yang diakibatkan oleh konstruksi hegemoni melalui penetrasi ideologi antar negara adikuasa, sebagaimana yang pernah menajam pasca Perang Dunia II (PD II).

Ulasan ilmiah Grinin dan Korotayev dalam artikelnya ${ }^{2}$ memberikan suatu pandangan bahwa Covid-19 memicu resesi dan krisis ekonomi global. Bahkan efek negatifnya dapat dikategorikan dalam skala katastropik. Hal tersebut tercermin dari munculnya fenomena negara adikuasa sekalipun tampak kepayahan dalam

2 Leonid Grinin dan Andrey Korotayev, Covid-19 Pandemic, Geopolitics, and Recession, Kertas Kerja Ke-4: International Center for Education and Social membendung efek destruktif Covid-19. Data perdagangan RRT mencatat bahwa negara Tirai Bambu tersebut dilanda ketidakpastian pada sektor ekonomi berupa kehilangan neraca ekspor sebesar $13 \%$ oleh karena pandemi menutup akses perdagangan produktif. Tentu saja besaran angka tersebut dapat dinilai signifikan bagi indikator stabilitas ekonomi negara produsen sekelas RRT.

Di pihak lain, Amerika Serikat (AS) sebagai negara adikuasa tradisional tersebut tengah diuji dengan membagi fokus antara kebijakan luar negerinya dengan persoalan pelik di dalam negeri. Pada dua minggu di akhir Bulan Maret 2020, AS mencatatkan rekor pengangguran yang mencapai 10 juta jiwa, data yang didasarkan pada angka aplikasi pencari kerja. Angka tersebut diprediksi akan terus bertambah hingga mencapai 39 juta jiwa pada pertengahan Mei 2020. Skala ketidakmenentuan stabilitas keamanan di AS juga semakin dipertajam oleh karena kondisi negara tersebut tengah mempersiapkan pemilihan umum presiden pada November 2020. Bahkan, tingkat ketegangan sosial terus meningkat disebabkan oleh kontestasi 2 (dua) partai politik di negara "Paman Sam" hingga melibatkan berbagai isu sensitif lain, seperti halnya rasialisme dan kemanusiaan. Kasus kematian George Floyd menjadi pewarna dalam dinamika drama mencekam di tengah pandemi yang memicu demo besar bertajuk "Black Lives Matter", mengusung isu-isu terkait rasialisme, diskriminasi, dan ketimpangan ekonomi.

Berbagai peristiwa yang melibatkan kondisi dalam negeri masing-masing negara adikuasa tersebut secara alamiah juga akan mempengaruhi secara luas tata hubungan internasional. Pandemi telah menciptakan panggung unjuk kekuatan antara AS dan RRT. Rivalitas geopolitik Abad ke-21 menempatkan RRT sebagai penantang serius untuk berhadap-hadapan secara ekonomi, politik maupun militer penguasa tradisional, AS terutama di kawasan regional Indo-Pasifik. Artinya, kondisi tersebut secara langsung maupun tidak akan berimplikasi serius terhadap situasi yang terjadi di Negara

and Humanitarian Studies (Moscow: Moscow State University, 2020: 5). 
Republik Indonesia; mencakup segala aspek strategis yang dikonsepsikan dalam astagatra $^{3}$. Sebagaimana diketahui bersama, letak geografis Indonesia yang diapit oleh Benua Asia dan Australia, Samudra Hindia dan Pasific, serta Laut China Selatan akan menjadi ruang penting bagi pertarungan hegemoni kedua negara tersebut.

Meskipun tengah dilanda krisis hebat di dalam negeri akibat pandemi, AS tidak segan melakukan penetrasi politik untuk memperkuat blokade pertahanannya untuk membendung kekuatan RRT di seluruh kawasan Asia. Hal tersebut dapat dilihat bagaimana Trump ${ }^{4}$ menempatkan India sebagai bagian strategis kebijakan luar negeri terpenting bagi AS. India secara geografis merupakan salah satu pintu penting untuk memasuki kawasan Asia Tenggara dan Australia. Tidak dapat dipungkiri, RRT dewasa ini memiliki pengaruh signifikan dan hubungan yang cukup mesra dengan negara-negara "pasar" di kawasan Indo-Pasifik, seperti Thailand, Vietnam, Singapura, dan Indonesia. Artinya, dengan menempatkan India sebagai "kawan baik" bagi AS, dalam perspektif geopolitik berarti memperpanjang bentang pagar sekaligus memperkuat garis pertahanan atas hegemoni negara Paman Sam tersebut di kawasan Indo-Pasifik, yakni menghidupkan kembali quad aliansi strategis antara AS, Jepang, India, dan Australia. $^{5}$

Untuk mengantarkan nilai penting hal tersebut, prolog dapat dimulai dengan meminjam pendapat Gökmen ${ }^{6}$, bahwa kajian geopolitik dilatarbelakangi oleh 2 (dua) fokus mendasar, yakni hegemoni dan pemetaannya-dapat digunakan untuk menelaah bentuk sekaligus mengukur cara pandang dunia, tentu saja dalam ikatan

\footnotetext{
3 Konsep geostrategi Indonesia terbagi dalam 8 (delapan aspek), terdiri dari 3 (tiga) gatra statis (trigatra) meliputi: Geografi, Demografi, dan Sumber Daya Alam (SDA), dan 5 (lima) gatra dinamis (pancagatra) meliputi aspek: ideologi, politik, ekonomi, sosial-budaya, serta pertahanankeamanan.

${ }^{4}$ Donald Trump Presiden AS ke-45
}

diskursus geografi dan politik. Kedua, ditambahkannya juga bahwa kajian geopolitik, termasuk di dalamnya yang dianggap tradisional sekalipun, tersusun dari asumsi dan cara pandang manusia terhadap dunia dalam kesatuan gambar terhadap aktivitas politiknya.

Jelas lah sampai di sini bagaimana geopolitik merupakan bagian dari wacana penting dalam pembahasan tentang krisis. Pemahaman pembacaan publik terhadap isuisu geopolitik akan memberikan gambaran utuh bagaimana kedudukan lembaga negara, pengampu kepentingan, bahkan warga negara berada dalam situasi kesemestaan potensi krisis terkait profil ideologi, politik, ekonomi, sosial, sosial-budaya dan pertahanankeamanan dengan kondisi geografis dan lingkungan hidupnya. Dalam aplikasinya di Indonesia, materi geopolitik sebagai kajian ilmiah ditransformasikan menjadi pengetahuan publik di jenjang perguruan tinggi melalui Mata Kuliah Wajib Umum (MKWU) Pendidikan Kewarganegaraan. Tidak terkecuali di Pendidikan Tinggi Keagamaan Islam Negeri (PTKIN), pembahasan geopolitik tersebut harus disampaikan dalam suatu materi yang terpadu dengan kesesuaian terhadap kurikulum di lembaga tersebut yang terikat pada nilai Islam sebagai identitas kajian.

\section{B. Jenis dan Alur Penelitian}

Artikel ini bermaksud membahas signifikansi kajian geopolitik, terutama wawasan nusantara sebagai asas dasar sekaligus sikap geopolotik bangsa Indonesia. Dalam khazanah ilmiah, artikel ini memuat usaha penelitian literatur (literature study) Bagian-bagian selanjutnya, akan dicoba untuk dapat disajikan bagaimana sejarah singkat pemikiran geopolitik dunia (world outlook) dan bagaimana lahirnya wawasan nusantara (national outlook). Setelah diperoleh pemahaman sejarah dan perkembangan

\footnotetext{
${ }^{5}$ The Warsawa Institute Review, Great Power Politics in The Post Covid-19, Artikel diupload 6 April 2020, diakses dari https://warsawinstitute.review/news-en/greatpower-politics-in-the-post-, pada 26 Juni 2020 (Warsawa, 2020: 2-3).

6 Semra R. Gökmen. Geopolitics and The Study of International Relations, (Ankara: Middle East of Technical University, 2010: 6 dan 10).
} 
pemikiran geopolitik dan pengaruhnya terhadap tatanan dunia, selanjutnya pembahasan akan diarahkan pada diskursus wawasan nusantara dalam bingkai pendidikan nasional, terutama bagaimana implementasinya di PTKIN. Artikel ini juga berupaya memformulasikan materi wawasan nusantara yang dikreasikan secara sederhana untuk PTKIN, sehingga konfigurasi materi yang telah disesuaikan dengan pedoman Keputusan Direktorat Jenderal Pendidikan Tinggi Nomor 43/Dikti/Kep/2006, sehingga antara kepentingan pembelajaran dan kepentingan nasional berjalan sinergis dan menghasilkan pemahaman konstruktif, terutama dalam mempersiapkan warga negara yang ulet dalam upaya menghadapi krisis, terutama yang berkaitan dengan sistem pertahanan nasional.

Adapun krisis yang dimaksud akan dinarasikan dalam bentuk gambaran tentang prediksi-prediksi yang didasarkan pada kejadian masa lalu dan perkembangan yang terjadi dewasa ini. Harapannya adalah merujuk pada kesiapsiagaan warga negara yang dimotori oleh peserta didik di lingkungan perguruan tinggi, terutama PTKIN. Adapun materi diformulasikan dengan memaksimalkan nilai kearifan Pancasila dengan mengakomodasi materi nilai Islam dan budaya lokal.

\section{Perkembangan Kajian Geopolitik dan Lahirnya Wawasan Nusantara}

Menelusuri kajian Geopolitik, maka akan diperoleh gambaran tentang bidang kajian multidisipliner dalam rumpun ilmu sosial yang secara garis besar membentangkan dua pokok kajian besar, meliputi kajian geografi dan politik. Dalam artikel ini akan dilakukan pembahasan yang sedikit berbeda dalam menguak terminologi geopolitik. Penelusuran makna tidak dilakukan secara etimologis, tetapi merujuk pada pergeseran paradigma terhadap kajian tersebut. Penelitian yang dilakukan Gökmen yang mencoba menguak keterkaitan antara geopolitik dengan ilmu hubungan internasional, diawali dengan penelusuran terhadap sejarah kajian geografi. Terminologi geografi dalam Encyclopedia Britannica dijelaskan sebagai ilmu tentang permukaan bumi yang menggambarkan dan menganalisa ragam ruang fisik, biologis, dan fenomena manusia yang tejadi di permukaan bumi, serta perilaku interrelasi diantaranya. Sebagai disiplin ilmu, geografi berkembang dan memiliki banyak cabang, sebagaimana meliputi: geografi pertanian, geografi ekonomi, geografi kependudukan, geografi urban dan sebagainya. Demikian juga dengan geografi politik merupakan cabang dari disiplin geografi hingga penemuan istilah "geopolitik" pada tahun $1899 .^{7}$

Pemikiran-pemikiran geopolitik di awal kelahirannya sebagai disiplin ilmu sangat dekat dengan kebudayaan Eropa di masa itu. Nama-nama seperti Friedrich Ratzel, Karl Haushofer, Rudolf Kjellen, Halford Mackinder merupakan penggagas awal dari disiplin geopolitik. Hadirnya disiplin tersebut tidak hanya diperuntukkan untuk mempertahankan hidup manusia, tetapi lebih ambisius darinya, geopolitik seakan menjadi kunci utama untuk menghegemonikan kekuasaan negara, dan berusaha sedikitnya mempengaruhi cara pandang negara lain terhadap wilayahnya secara ideologis, hingga dalam konteks lebih ofensif menyaplok kekuasaan negara lain dengan upaya kolonialisasi. Seperti di ketahui bersama, pada kurun waktu Abad ke-16 hingga awal Abad ke-20, negara-negara di Eropa tengah disibukkan dengan upaya kolonialisasi terhadap negara-negara lemah di kawasan luar benuanya untuk dapat mengeruk sumberdaya alam, dan senantiasa memperkuat pengaruh sekaligus hegemoni di antara negara benua biru tersebut.

Friedrich Ratzel misalnya, menganalogikan "negara" sebagai "organisme" atau "mahluk hidup". Siklus kehidupan negara selayaknya hukum biologis, dengan menempatkan teritori sebagai tubuh, mengakar dalam tanah kelahirannya. Ukuran dari pertumbuhan sebuah negara dapat dilihat sejauhmana dapat berkembang secara kewilayahannya. Negara yang sehat adalah

\footnotetext{
${ }^{7}$ Gökmen, Semra R., op.cit. hlm. 11.
} 
negara yang mampu menyerap saripati nutrisi dengan memakan negara-negara yang lebih kecil. Ratzel terpengaruh oleh teori seleksi alam Charles Darwin, terutama pada teori "survival of the fittest". 8

Terpengaruh oleh Ratzel, Rudolf Kjellen memperluas dan memperdalam pandangan teori negara organik tersebut hingga sampai pada pemaknaan ideologis. Bagi Kjellen, negara memang membutuhkan wilayah untuk berkembang. Meskipun demikian, motor utama untuk dapat menggerakkan batas-batas kewilayahan suatu negara lebih diserahkan kepada budaya. Konsepsi "budaya unggul" secara alamiah akan memperluas kewilayahan dengan lebih elegan, legal, dan tidak menafikan aspirasi kemanusiaan. Batas wilayah suatu negara tidak lah berbentuk tembok yang terbuat dari batu. Bersamaan dengan pandangan tentang negara organisme ideologis tersebut, Kjellen juga meletakkan pandangan penting lainnya yang selanjutnya disebut dengan autarki ${ }^{9}$. Autarki baginya tidak hanya memberikan kecukupan kebutuhan warga negara, melainkan juga bermakna sebagai kekuatan untuk berkembang, baik secara teritorial maupun ideologi. ${ }^{10}$

Pandangan lain geopolitik dikemukakan oleh Sir Harfold Mackinder. Disebut-sebut sebagai orang yang mengembangkan geopolitik baik dalam aspek pratik maupun teori. Pada kenyataannya Mackinder mampu memetakan sebaran kekuasaan dan hegemoni baru saat itu melalui pemetaan sejarah kekuasaan. Apa yang paling mahsyur dalam pandangan Mackinder adalah "heartland theory". Teori tersebut meletakkan "daerah jantung" sebagai daerah inti yang menentukan titik penguasaan dunia. Apa yang dimaksud dengan daerah jantung tersebut merujuk

\footnotetext{
${ }^{8}$ Semra R. Gökmen, op.cit. hlm. 23-25.

9 Autarki sering disebut sebagai swasembada, terutama merujuk pada wacana perdagangan internasional dan kebijakan ekonomi protektorat: perlindungan pada produk lokal atas kompetisi internasional. Lihat E.P. Torkanovskiy, In Defence of Autarky as a Modern Way of National Economic
}

pada bentang benua Eropa dan Asia (Eurasia), sehingga penguasaan dari padanya memiliki arti penguasaan terhadap dunia. Pada konsepsi tersebutlah Mackinder diidentifikasi sebagai penggagas "wawasan benua". 11

Pergeseran paradigma tentang geopolitik terjadi seiring dengan perubahan zaman, terutama pasca Perang Dunia II (PD II). Geopolitik tidak lagi meletakkan pandangan bagaimana suatu negara secara ofensif memperluas eksistensi kewilayahannya dengan jalan militer. Hal tersebut didorong oleh karena terjadinya PD II yang telah banyak menafikan sisi kemanusiaan dari berbagai perspektif kehidupan. Kesadaran untuk "menyelamatkan" bumi dari kehancuran oleh karena hasrat penguasaan yang dipenetrasikan melalui perang fisik maupun perang asimetris harus segera dihentikan, meskipun bipolarisasi ketegangan terhadapnya tidak surut begitu saja dalam waktu yang singkat. PD II memang telah usai, tetapi perang dunia yang membagi dunia dalam faksi politik masih terasa setidaknya hingga tahun 1990-an.

Sama halnya ketika membicarakan konsepsi geopolitik Indonesia, tentu saja tidak dapat diletakkan dengan geopolitik pasca PD II. Berangkat dari titik jembatan emas kemerdekaan Indonesia, Proklamasi 17 Agustus 1945 berhasil dilakukan memanfaatkan penetrasi politik saat dunia tengah berupaya mengakhiri kekacauan akibat perang panjang tersebut. Menyadari sepenuhnya atas kesukaran proses rekonstruksi dunia pasca PD II, founding fathers Indonesia berupaya menghindari bipolarisasi kuasa dunia yang terbagi atas Blok Barat dengan Timur.

Kehancuran fasisme yang ditandai oleh kehancuran NAZI Jerman dan chauvinisme Jepang, tidak serta merta mendamaikan Dunia. Pada kenyataannya jargon kapitalisme vis a vis komunisme terus bersitegang hingga saat ini. Perang saudara di RRT yang melibatkan dua ideologi tersebut pada akhirnya dimenangkan oleh komunisme. Masih dalam kawasan

Development, Journal of International Economic Affairs Vol. 9 No. 1, Maret 2019, hlm. 157-168 (Moskow: Journal of International Economic Affairs, 2019: 166)

${ }^{10}$ Semra R. Gökmen, op.cit. hlm. 27-28.

${ }^{11}$ Dwi Sulisworo, T., et al., Bahan Ajar: Geopolitik Indonesia (Yogyakarta: Universitas Ahmad Dahlan, 2020:5). 
regional yang sama, perang saudara dengan latar belakang perebutan pengaruh dua ideologi besar tersebut juga telah membelah Korea menjadi dua arah mata angin, yakni Utara dan Selatan. Demikian juga dengan apa yang terjadi di negaranegara kawasan Asia Tenggara, sebagaimana perang saudara di Vietnam dan Kamboja. Indonesia pun tidak luput dari dampak dikotomi ideologis, sebagaimana puncaknya terjadi pada tahun 1965 yang melibatkan ketegangan antara faksi besar politik, terutama militer dengan komunis. Perang dingin dan pengaruhnya terus berkecamuk hingga setidaknya mereda saat Tembok Berlin berhasil diruntuhkan pada tahun 1990, sebagai simbol bersatunya Jerman yang sebelumnya sempat dipisahkan dua arah mata angin, barat dan timur sebagai representasi kapitalisme dan komunisme. Deskripsi atas perang dingin tersebut menandakan bahwa pengaruh kekuasaan adikuasa melalui gempuran ideologi belum lah padam.

Sadar akan hal tersebut, sebagai upaya melestarikan kedaulatan negara pasca proklamasi Republik Indonesia, dan langkah antisipasi gejolak ideologi sebagaimana pengaruh besar atas dua blok ideologi tersebut, telah dicantumkan dalam Pembukaan Undang-Undang Dasar 1945. Sebagai nota konstitusi, founding fathers menyisipkan pernyataan sikap sekaligus visi dan tujuan berdirinya Negara Republik Indonesia, yakni: "ikut melaksanakan ketertiban dunia yang berdasarkan kemerdekaan, perdamaian abadi, dan keadilan sosial". Berdasarkan hal tersebut, maka dapat diartikan juga bahwa asas geopolitik Indonesia adalah "bebasaktif"- -tidak memihak pada faksi kuasa atau blok ideologi tertentu-berorientasi kepada perdamaian dengan sikap defensif dengan tujuan semata-mata untuk melindungi tumpah darah dan mewujudkan keadilan sosial.

Sebagaimana telah sedikit disinggung sebelumnya, berakhirnya PD II tidak serta- merta menghentikan perang dalam arti menyeluruh. Lebih-lebih dalam arti ideologi, perang dingin merupakan gambaran bahwa api sekam konflik masih terjadi hingga era kontemporer. Potensi terjadinya kembali perang dunia merupakan bahaya laten yang tidak dapat dipungkiri, sehingga diperlukan suatu sistem pertahanan nasional yang berwawasan ke dalam maupun luar. Atas pertimbangan kedaulatan dan mendesaknya sistem pertahanan nasional, maka diperlukan suatu langkah strategis yang diilhami dari kemampuan cara pandang Bangsa Indonesia terhadap diri dan lingkungannya, sebagaimana yang telah disebutkan sebelumnya sebagai sikap sekaligus kemampuan geopolitik Indonesia. Sikap dan kemampuan tersebut sering disebut sebagai wawasan nusantara (national outlook), dan seringkali dipadankan dengan archipelago insight. Sikap geopolitik Indonesia dilatarbelakangi oleh kondisi alamiah geografi Negara Republik Indonesia, tersusun dari kontur geografis kepulauan, atau terbentuk dari kekayaan kewilayahan terdiri dari gugusan pulau dan membentuk identitas nasional sebagai negara-bangsa (nation state).

Meskipun demikian, sesungguhnya geopolitik Indonesia tidak hanya terbatas dalam aspek cara pandang kewilayahan, yang memadukan antara wawasan kemaritiman dan kepulauan. Lebih dari itu, letak strategis Indonesia yang terletak diantara silang benua, memberikan pemahaman bahwa wawasan nusantara juga akan terkait persoalan ideologi. Artikel ini tidak akan secara spesifik membahas geostrategi ${ }^{12}$ Indonesia sebagai langkah lanjut geopolitik, tetapi setidaknya akan diungkap bagaimana cara kerja wawasan nusantara dalam menangkap subjek kajian geostrategi yang akan dibahas pada bagian selanjutnya. Sebelum membahas hal tersebut, akan menjadi lebih baik dalam hal ini dapat disajikan terlebih dahulu tentang sejarah wawasan nusantara itu sendiri, sehingga diperoleh gambaran utuh mengapa satu hal akan terkait dengan hal lainnya.

Menurut catatan sejarah, wawasan nusantara mulai dikenal saat Perdana Menteri Ir. H. Djuanda Kartawidjaja menggaungkan

\footnotetext{
12 Geostrategi Indonesia sering disebut dengan konsep ketahanan nasional
} 
suatu deklarasi kewilayahan pada tanggal 13 Desember 1957. Deklarasi yang kemudian lebih populer sebagai "Deklarasi Djuanda" tersebut, merupakan suatu upaya pemerintah saat itu untuk menjawab persoalan mendesak dalam hal kedaulatan wilayah, tidak sebatas dimaknai sebagai garis lingkar pelindung kedaulatan negara saja, tetapi juga upaya politis yang nyata untuk melindungi kekayaan alam yang terdapat di dalamnya. Sebagaimana dalam syarat berdirinya sebuah negara, wilayah dan batasnya merupakan bagian manunggal yang tidak dapat dipisahkan dengan rakyat, maupun ideologinya.

Hadirnya Deklarasi Djuanda dalam perspektif hukum internasional juga berarti nota kekuasaan pemerintah yang sah untuk mengelola wilayahnya sendiri tanpa campur tangan pihak asing mana pun, sekaligus implementasi preambule UUD 1945, yakni untuk melindungi segenap tumpah darah Indonesia dengan bentuk hukum yang diakui secara internasional. Dapat dikatakan demikian karena sebelum Deklarasi Djuanda diakui secara internasional, hukum kewilayahan Indonesia yang meliputi daratan dan lautan terikat pada hukum buatan kolonialisme Belanda, Territoriale Zee en Mariteme Kringen Ordonatie (TZMKO) yang digagas oleh pemerintahan Ratu Wilhelmina ${ }^{13}$ tersebut pada Tahun 1939.

Penjelasan terhadap TZMKO atau dikenal dengan sebutan lain sebagai Ordonasi 1939, merupakan tata hukum yang sangat merugikan Negara Republik Indonesia apabila merujuk pada konsep negara-bangsa sebagai kesatuan wilayahrakyat-ideologi. Ordonasi 1939 diadopsi dari cara pandang kewilayahan yang didasarkan satuan pulau, sehingga terbentang jarak antar pulau yang dapat menjadi celah retaknya kesatuan kedaulatan. Pengukurannya dilakukan melalui penarikan garis lebar dari pangkal

\footnotetext{
13 Wilhelmina Helena Pauline Marie van OranjeNassau (31 Agustus 1880-28 November 1962), merupakan Ratu Belanda sejak tahun 1890 hingga 1948, digantikan oleh Juliana Louise Marie Wilhelmina van Oranje-Nassau.
}

pasang-surut pantai pulau tertentu sejauh 3 (tiga) Mil laut, sehingga hal tersebut memiliki arti bahwa dalam satu pulau hanya memiliki wilayah perairan sejauh 3 (tiga) Mil di sekelilingnya. ${ }^{14}$ Tentu saja pengukuran kewilayahan tersebut menjadi titik lemah kedaulatan bangsa, karena terdapat perairan bebas selepas 3 (tiga) Mil dari kontur pulau, sehingga dengan mudah negara asing mengintai segala aktivitas strategis negara melalui pelayaran kapal-kapal asing yang dilindungi oleh Ordonasi 1939 tersebut.

Menjawab celah kedaulatan tersebut, Deklarasi Djuanda 1957 mendekonstruksi Ordonasi 1939 dengan mengubah pengukuran satuan pulau menjadi kesatuan kepulauan. Pengukuran dalam Deklarasi Djuanda didasarkan pada garis yang terhubung dari titik-titik terluar kepulauan dalam wilayah kedaulatan Indonesia, selebar 12 Mil laut, sehingga perairan yang terdapat dalam kepulauan tersebut sepenuhnya secara politis merupakan kekuasaan negara, demikian selanjutnya kapal asing yang bermaksud berlayar melintas perairan dalam wilayah kepulauan harus terlebih dahulu mendapatkan izin dari otoritas negara. Dalam arti lain, Deklarasi Djuanda 1957 juga merubah makna perairan teritorial Indonesia. Ordonasi 1939 memberikan arti perairan laut dalam di Indonesia sebagai jarak pemisah antar pulau, sedangkan Deklarasi Djuanda 1957 justru memberikan pemaknaan terhadap kawasan perairan tersebut sebagai penghubung antar pulau sekaligus kekayaan alam yang pengelolaannya daulat negara.

Perlu diketahui, Deklarasi Djuanda 1957 merupakan cikal-bakal hukum laut internasional, sehingga dapat dikatakan bahwa dengan deklarasi tersebut, Indonesia telah mengukir sejarah, memberikan sumbangsih nyata bagi perkembangan hukum laut internasional sekaligus ilmu hukum serta kajian politik internasional. Pada tanggal 30 April 1980, dokumen konvensi hukum laut internasional yang kemudian disebut dengan

14 Direktorat Jenderal Pembelajaran dan Kemahasiswaan Kementerian Riset, Teknologi, dan Pendidikan Tinggi, Buku Ajar Mata Kuliah Wajib Umum: Pendidikan Kewarganegaraan (Jakarta: Dirjen Pembelajaran dan Kemahasiswaan Kemenristekdikti, 2016: 218-220) 
"The United Nation Convention on The Law of The Sea" (UNCLOS) berhasil disusun diilhami dari isi konsepsi Deklarasi Djuanda 1957 tersebut. Salah satu gagasan yang muncul dalam UNCLOS adalah asas negara kepulauan (archipelago state), dan Indonesia merupakan salah satu bagian di dalamnya. Selanjutnya sebagai upaya proteksi hukum atas pengakuan tersebut, pemerintah meratifikasi UNCLOS $1982 \mathrm{ke}$ dalam Undang-undang (UU) Nomor 17 Tahun 1985 Tentang Hukum Laut, sehingga bersamaan dengannya kedaulatan kewilayahan Negara Republik Indonesia menjadi jauh lebih luas dibanding apa yang diatur oleh Ordonasi 1939, yakni mencapai 5.9 juta $\mathrm{Km}^{2}$, perinciannya meliputi sebesar 3.2 juta $\mathrm{Km}^{2}$ merupakan perairan teritorial dan 2.7 juta $\mathrm{Km}^{2}$ perairan Zona Ekonomi Ekslusif. ${ }^{15}$

Tentu saja capaian perjuangan Bangsa Indonesia yang diawali dari Deklarasi Djuanda 1957 hingga menjadi pedoman asas negara kepulauan dalam hukum internasional tersebut merupakan hal yang luar biasa. Dampak positif dari hal tersebut sangat jelas, rakyat Indonesia hingga pada hari ini dilindungi secara hukum, baik nasional maupun internasional, untuk dapat memanfaatkan segala potensi kekayaan yang terkandung di seluruh wilayah perairan kedaulatan negara. Meskipun demikian, pembahasan atas kesadaran warga negara terhadap wilayah kedaulatan nusantara belum lah usai. Banyak terjadi pelanggaran wilayah yang dilakukan oleh negara asing, bahkan terjadi eksploitasi kekayaan alam yang dilakukan baik oleh pihak asing maupun anak bangsa yang cenderung membahayakan kelestarian alam. Kembali kepada teori besar tentang geopolitik, kajian wawasan nusantara tidak dapat dipisahkan kajian-kajian lain sebagai pembentuk kesadaran atas pemahaman negara-bangsa (nation-state), sehingga tidak dapat dinafikan pembahasan tentang budaya lokal, ideologi dan tantangannya. Untuk membentuk pemahaman tersebut,

\footnotetext{
15 Ibid. hlm. 220-221

16 Notonagoro, Pancasila Secara IImiah Populer (Jakarta: Pantjuran Tudjuh, 1975:32-33).
}

maka dalam artikel ini secara terpisah akan dibahas pada bagian-bagian berikutnya.

\section{Budaya Lokal, Ideologi Ketuhanan, dan Tantangan Primordialisme}

Agenda penting geopolitik Indonesia tidak dapat dilepaskan dari Pancasila sebagai filsafat dasar negara dan bangsa Indonesia. Dalam pandangan Notonagoro ${ }^{16}$, tata runtut logika kausalitas (sebab-akibat), maka apa yang menjadi "sebab material" (causa materialis) Pancasila meliputi unsur-unsur diantaranya adat, budaya, dan agama yang secara alamiah telah terdapat dalam diri Bangsa Indonesia itu sendiri. Miska Amien, menerjemahkan unsur causa materialis tersebut dalam pemahaman yang gestalt melalui adat sebagai wujud ideal kebudayaan dengan merangkum pandangan sosiologi Koentjaraningrat dan etika sosial Herman De Vos.

De Vos meletakkan adat-istiadat dalam dua aspek penting, meliputi aspek subjek kepemilikan dan aspek mekanisme geraknya. Subjek kepemilikan yang dimaksud merujuk pada kelompok, bukan perorangan. Hal tersebut merupakan gambaran dari bentuk penerimaan secara de facto terhadap hasil tata laku kehidupan manusia dalam komunitas masyarakat. ${ }^{17}$ Dapat diartikan juga bahwa penerimaan tata lau tersebut merupakan kontrak sosial tidak tertulis yang dikristalisasi dalam "tata kewajaran" kehidupan. Aturanaturan dikodifikasikan secara spesifik memberikan suatu pengertian tentang apa yang dianggap layak, baik, sewajarnya mengalir tanpa terdapat perlawanan, atau suatu tata nilai yang diterima begitu saja oleh masyarakat tanpa mempertanyakan kembali hakikat, asalusul keberadaannya, maupun tujuannya.

Hampir senada dengan pandangan De Vos, Koentjaraningrat meletakkan pandangan tentang adat-istiadat sebagai bentuk ideal kebudayaan, dan secara khusus terstratifikasi dalam 4 (empat) tingkatan, meliputi: (i) tingkat nilai budaya; (ii) tingkat norma-norma; (iii) tingkat hukum; dan (iv) tingkat aturan

\footnotetext{
${ }^{17}$ M. Miska Amien. Causa Materialis Pancasila Menurut Notonegoro, Jurnal Filsafat Vol. 39 No. 1 April 2006, hlm 18-26 (Yogyakarta: Fakultas Filsafat Yogyakarta, 2006: 19-20)
} 
khusus. ${ }^{18}$ Demikian pula dengan cara pandang Bangsa Indonesia terhadap diri dan lingkungannya, terbentuk dari berbagai aspek ideologis yang melingkupinya, termasuk di dalamnya adat dan budaya lokal yang terlebih dahulu telah ada sebelum konsep Kebangsaan Indonesia terbentuk. Untuk memperkuat pendapat tersebut, merujuk pada pandangan Kusnanto Anggoro, memahami geopolitik maupun geostrategi berarti memperhitungkan segala aspek yang tidak tampak (intangible). Berarti pula bahwa pemahaman harus didasarkan pada keutuhan dinamika, termasuk di dalamnya kesadaran subjek dari geopolitik itu sendiri. ${ }^{19}$

Berdasarkan pengertian tersebut, maka pemahaman Bangsa Indonesia terhadap diri dan wilayah hidupnya tidak dapat dipisahkan dari nilai-nilai kosmologis budayanya. Sebagai contoh, masyarakat Hindu nusantara memahami ruang hidupnya dengan meletakkan konsep iman "Tri Hita Karana" dengan tujuan terciptanya harmoni antara subjek kesadaran dan ruang hidup. Kosmologi tersebut menempatkan eksistensi manusia sebagai individu tidak dapat dilepaskan oleh realitas di luarnya, sedikitnya membutuhkan daya (Prana) yang memperantarai antara jiwa (Atman)sebagai manifestasi daya Tuhan-dengan tubuh manusia itu sendiri. Manusia secara kausal akan berinteraksi dengan alam sebagai ruang hidup, termasuk dengan berbagai anasir pembentuknya sebagaimana air, api, udara, dan tanah. ${ }^{20}$

Bergeser pada kosmologi masyarakat Jawa kuno, terutama pada konsep hubungan manusia dengan lingkungannya

18 Koentjaraningrat, Kebudayaan Mentalitet dan Pembangunan (Jakarta: Gramedia, 1974: 20). Dibahas dalam M. Miska Amien. Causa Materialis Pancasila Menurut Notonegoro, Jurnal Filsafat Vol. 39 No. 1 April 2006, hlm 18-26 (Yogyakarta: Fakultas Filsafat Yogyakarta, 2006: 19-20).

19 Kusnanto Anggoro. Perubahan Geopolitik dan Ketahanan Nasional: Sebuah Penjelajahan Teoretikal, Jurnal: Kajian Lembaga Ketahanan Nasional Republik Indonesia Edisi 29 Maret 2017, hlm 5-16 (Jakarta: Lembaga Ketahanan Nasional, 2017: 6) yang terangkum pada filosofi "Memayu Hayuning Bawana". Berkaitan dengan konsep geopolitik, Memayu Hayuning Bawana meletakkan manusia sebagai subjek sekaligus aktor utama atas keteraturan alam; yakni dengan segenap kesadarannya manusia memaknai keteraturan yang telah dilekatkan kepada alam oleh Tuhan. Endraswara memberikan gambaran terhadap hubungan tersebut sebagai jalinan otoritas mikro kosmos dengan makro kosmos yang menempatkan manusia sebagai pola dasar pembentukan keteraturan alam itu sendiri. ${ }^{21}$

Pemahaman kosmologis serupa juga tampak pada berbagai kearifan lokal lain di Indonesia, seperti masyarakat Biak di Papua yang terikat oleh "Faknik"22, mitologi "Sampulo Padari" pada masyarakat Dayak Tamambaloh di Kalimantan Barat, atau kosmologi "Mopahilolonga Katuvua" pada masyarakat Tore, Sulawesi Tengah. Keterkaitan hubungan ego-sosio-religius tersebut menjadi bukti bahwa pemahaman Bangsa Indonesia terhadap wilayahnya tidak dapat dipisahkan dari kesadaran ideologis. Demikian juga dengan pandangan kosmologi nusantara yang berasal dari proses akulturasi budaya. Hal tersebut dapat dilihat pada tradisi "Belale" kebudayaan masyarakat Melayu Sambas, Kalimantan Barat yang terpengaruh ideologi Islam, terutama konsep tauhid. Belale' merupakan tradisi gotong-royong pada kegiatan tanam padi masyarakat setempat yang didasarkan pada kepatuhan atas ikatan hubungan manusia dengan Tuhannya (habluminallah), hubungan manusia di lingkup sosial (hablumminannas) dan hubungan manusia dalam kesemestaan alam

\footnotetext{
20 Putu Sudira. Konsep dan Praksis Pendidikan Hindu Berbasis Tri Hita Karana. Makalah Seminar Eksistensi Pendidikan Hindu dalam Sisdiknas di Era Global (Yogyakarta: Universitas Negeri Yogyakarta, 2014: 6-7) 21 Suwardi Endraswara. Memayu Hayuning Bawana: Laku Menuju Keselamatan dan Kebahagiaan Hidup Orang Jawa (Yogyakarta: Penerbit NARASI, 2013:143).

22 Lihat Efriani, et.al. Desain Kosmologi Sebagai Konservasi Alam Pada Komunitas Dayak Tamambaloh di Kalimantan Barat, Jurnal: An1mage Jurnal Studi Desain Vol. 2 No. 2, 2019 hlm. 66-74 (Tangerang Selatan: AJSD, 2019)
} 
sebagai ruang hidupnya (hablumminal 'alam). ${ }^{23}$

Kembali pada pembahasan geopolitik, dapat ditarik kesimpulan bahwa berdasarkan berbagai catatan kebudayaan nusantara, wawasan nusantara sebagai nota geopolitik Negara Kesatuan Republik Indonesia pada dasarnya diikat oleh nilai universalitas yang mengerucut pada nilainilai ketuhanan, sebagai landasan hubungan sosial dan kewilayahannya. Dipahami juga bagaimana Pancasila dan kesatuan geografis sebagaimana tergambar pada semangat Deklarasi Djuanda 1957 adalah satu kesatuan utuh tanpa dapat dipisahkan satu sama lain. Nilai universalitas tersebut merajut kemajemukan budaya dalam satu identitas, sehingga menjadi beralasan jika Indonesia sering disebut sebagai negara-bangsa. Apa yang perlu dipahami atas kesatuan budaya tersebut bukan lah penyeragaman atas keberagamannya, melainkan memberikan peranan kepada nilai universalitas luhur yang terdapat pada masing-masing budaya tersebut, dan selanjutnya diikat pada identitas kebangsaan. Menggarisbawahi pandangan Kjellen sebagaimana disinggung pada bagian sebelumnya, bahwa hanya dengan budaya yang kuat lah suatu bangsa dapat menciptakan ruang hidupnya untuk terus berkembang, dan mampu mengemban identitas kebangsaannya.

Meskipun keberagaman tersebut merupakan penjelmaan kekayaan dari identitas kebangsaan, bersamaan dengannya dalam beberapa kasus seringkali justru muncul sebagai celah yang mengkhawatirkan. Armaidy Armawi menggarisbawahi catatan Cliford Geertz atas sentimen primordial yang mengganggu bentuk kesatuan negarabangsa Indonesia. Meskipun pluralitas etnik, agama, dan budaya merupakan kekuatan pontensial bagi ketahanan nasional (national resillience), bersamaan

\footnotetext{
${ }^{23}$ Ma'ruf dan Abdur Rasyid, Nilai-nilai Pendidikan Islam Dalam Tradisi Belalek (Pontianak: IAIN Pontianak, 2019:56-67)

${ }^{24}$ Armaidy Armawi. Pengembangan Wawasan

Nusantara Menuju Ketahanan Nasional, Jurnal
}

dengannya tampaknya diperlukan perawatan khusus sehingga perbedaan tidak mengganggu stabilitas nasional. Perilaku yang sering ditemui dalam kehidupan keseharian, yakni penggunaan atribut primordial yang disematkan dalam tata sosial yang luas, seperti halnya penyematan pada jabatan politik, status sosial, tata kelola kelembagaan, atau dalam tata kehidupan lain. Geertz menyebutnya sebagai primordial sentiment atau attachment. Hal tersebut menyebabkan terganggunya civil politics sebagai motor penggerak kebangsaan. ${ }^{24}$

Letak tantangannya terdapat pada tingkah laku politik yang dikuasai oleh kultus yang bersifat a priori (given) seperti kesukuan, kedaerahan-wilayah, keluarga dalam identitas talian darah, akan menciptakan perilaku politik identitas yang melembaga dan kontra produktif terhadap geopolitik dalam cara pandang negara-bangsa. Diperlukan suatu upaya yang besar untuk menghapus prasangka-prasangka sosial yang disebabkan oleh primordial sentiment tersebut. Gerak integrasi (integrative revolution) menjadi jawaban atas kehadiran politik identitas tersebut. Artinya adalah wawasan nusantara harus dilandaskan pada kesatuan sistem wilayah-ideologi-budaya yang lebih luas, yakni kesatuan wilayah fisik sebagaimana semangat Deklarasi Djuanda 1957, semangat kebangsaan sebagaimana dijiwai oleh Sumpah Pemuda 1928. ${ }^{25}$

Pada tantangan tersebut lah pembangunan karakter dan kebangsaan melalui pendidikan kewarganegaraan, terutama dalam materi geopolitik memiliki peranan yang sangat besar dalam mengurai masalah primordial attachment tersebut. Meskipun realitas keberagaman bangsa Indonesia secara parsial merupakan hal-hal yang berbeda satu sama lain, tetapi universalitas nilai moral good dari setiap ideologi suku, kontur daerah, agama dan kepercayaan adalah sama. Nilai ketuhanan telah melandasi sebagai nilai hidup dari kebangsaan yang utuh, diikat oleh bentang wilayah kedaulatan sebagai identitas nasional.

Ketahanan Nasional Vol. XIV No. 3 2009, hlm. 1-13

(Yogyakarta: Universitas Gadjah Mada, 2009: 5-6)

25 Ibid. 
Fokus kritik dapat diarahkan kepada penyimpangan penyelenggaraan negara, distribusi kesejahteraan, dan kepentingan kelompok pada penguasaan. Geopolitik Indonesia merupakan hasil perjuangan panjang bangsa, yang seharusnya tidak dikotori oleh kepentingan faksi politik tertentu.

\section{E. Implementasi Meteri Wawasan Nusantara di PTKIN}

Globalisasi merupakan suatu ontologi tentang ambivalensi. Di satu sisi keberadaannya menghapus batas kewilayahan menggunakan aspek mental, sebagaimana meningkatnya kesadaraan manusia tentang kebebasan, keadilan, kemerdekaan, atau kesejahteraan sosial. Bertolak belakang dengan semangat tersebut, terdapat fenomena unik globalisasi dan pengaruhnya terhadap gerak kebudayaan dunia yang cenderung homogen, bahkan terkesan sengaja melibatkan upaya homogenisasi kultural.

Menariknya, berbagai fenomena Covid-19 sebagai representasi krisis kesehatan meneguhkan kembali catatancatatan penting dalam kajian geopolitik. Terlebih membukakan mata bahwa globalisasi dalam kasus tertentu tidak sertamerta dapat diletakkan sebagai dunia tanpa batas (borderless). Kebijakan lockdown dalam kasus penanggulangan penyebaran Covid-19 di berbagai negara menunjukkan bahwa sekat dan batas negara masih dibutuhkan untuk menyelamatkan negara dari bahaya krisis. Demikian pentingnya kajian geopolitik ini, tentu saja menjadi sangat mendesak bagaimana pemahaman tentangnya dapat ditransformasikan menjadi pengetahuan publik, terutama dalam hal pembacaan warga negara terhadap fenomena krisis yang berkembang di lingkungannya dan tentu saja bersamaan dengan langkah mitigasinya.

Pada tahap tersebut materi wawasan nusantara sebagai nota geopolitik kewarganegaraan dianggap mendesak untuk dapat ditransformasikan menjadi tata laku pada kehidupan masyarakat yang terikat hak dan kewajibannya sebagai warga negara. Sebenarnya gagasan tersebut telah diatur oleh undang-undang, sebagaimana dalam Undang-Undang (UU) No. 3 Tahun 2002 tentang Pertahanan Negara, terutama dalam pasal 9 (sembilan) ayat 2 (dua), bahwa "Keikutsertaan warga negara dalam upaya bela negara, sebagaimana yang dimaksud ayat (1), diselenggarakan melalui (a) pendidikan kewarganegaraan....". Adapun perlindungan implementasi UU tersebut, maka pada perguruan tinggi termasuk dalam PTKIN, pendidikan kewarganegaraan diselenggarakan secara wajib sebagai Mata Kuliah Wajib Umum (MKWU). Hal tersebut dapat dilihat sebagaimana amanat dari UU No.12 Tahun 2012 Pasal 35 tentang Pendidikan Tinggi, serta materi geopolitik Indonesia secara hukum wajib untuk disampaikan dalam MKWU Pendidikan Kewarganegaraan, sesuai dengan Keputusan Dirjen Pendidikan Tinggi No. 43/DIKTI/KEP/2006.

Tentu saja agenda sekaligus harapan atas capaian dalam UU tersebut tidak hanya diinterpretasikan sebagai kemampuan peserta didik dalam konsep dalam perspektif ilmiah atau kemampuan profesional warga negara. Lebih dari itu, Capaian Pembelajaran Lulusan (CPL) merupakan agenda ideologis yang harus dapat di raih dalam bentuk pembangunan karakter kebangsaan warga negara (nationalcharacter building). Mengacu pada Kerangka Kualifikasi Nasional Indonesia (KKNI) yang dipedomani berdasar Peraturan Menteri Riset Teknologi dan Perguruan Tinggi Republik Indonesia (Permenristekdikti RI) No. 44, Tahun 2015 tentang Standar Nasional Perguruan Tinggi, output pendidikan nasional termasuk di dalamnya materi dan proses pembelajarannya harus jelas dapat diimplementasikan dalam kehidupan keseharian.

Hal tersebut berlaku untuk semua lembaga pendidikan tinggi tanpa kecuali, termasuk di dalamnya PTKIN. Peran PTKIN dalam menransformasikan pendidikan geopolitik melalui pendidikan kewarganegaraan sangat 
besar. Azyumardi Azra ${ }^{26}$ berpendapat bahwa mayoritas penduduk Indonesia yang memeluk agama Islam membuat lembaga pendidikan keagamaan tersebut memiliki peranan yang sangat penting bagi penguatan pendidikan kewarganegaraan dalam membangun demokrasi.

PTKIN sebagai lembaga pemangku amanat tri dharma perguruan tinggi berkarakteristik dan corak semangat nilai keluhuran Islam, memang seharusnya mampu menjembatani proses transformasi peserta didik kepada warga negara yang mampu memahami, menganalisis, sekaligus mengaplikasikan, bahkan menjadi prakarsa ide-ide strategis kepentingan maupun pembangunan nasional berdasar Pancasila. Tantangannya terletak pada sering terjadinya peletakkan aras pemikiran antara kebenaran Islam vis a vis Pancasila dalam konteks terpisah dan berbeda. Dalam hal ini, apa yang seharusnya dilakukan adalah menelisik bagaimana Islam sebagai sumber kebenaran yang diadopsi oleh Pancasila sebagai ideologi terbuka, sebagaimana peran ideologi lain terhadapnya. Untuk selanjutnya, Pancasila dapat dibingkai dalam ikatan sosial-kebangsaan warga negara sehingga identitas nasional terakomodasi, sebagaimana nota yang tercantum dalam sila I (pertama).

Melangkah pada pengembangan materi geopolitik Indonesia, yakni wawasan nusantara, didasarkan pada segala potensi kewilayahan yang diikat oleh kesatuan politik dan ideologi kebangsaan Indonesia, sehingga apa yang dicapai terhadapnya, menjadi sikap keseharian warga negara sebagai suatu identitas kebangsaaan. Bersamaan dengan hal tersebut, materi tentang diskursus globalisasi yang mencakup realitas aktual di dalamnya, dikembangkan untuk membentuk visi warga negara Indonesia sebagai bagian dari masyarakat global. Hal tersebut, sejak awal telah disadari oleh para founding fathers, bahwa pendidikan nasional merupakan

\footnotetext{
${ }^{26}$ Azyumardi Azra, Civic Education at Public Islamic Higher Education (PTKIN) and Pesantren, Tarbiya: Journal of Education in Muslim Society Vol. 2 No. 2. Desember 2015, hlm 167-177 (Jakarta: Syarif
}

rahim dari kebudayaan nasional, sehingga karakter pendidikan yang beridentitas ideologi Pancasila merupakan hal mutlak harus dipenuhi.

Gagasan tersebut ditangkap baik oleh pelopor pendidikan nasional, Ki Hadjar Dewantara. Setidaknya terdapat tiga hal penting yang perlu dipertimbangkan oleh dunia pendidikan nasional dalam sumbangsihnya terhadap kebudayaan nasional, yakni memuat tiga konsep penting yang diringkas dalam akronim Trikon: kontinuitas; konvergensi; dan konsentrisitas ${ }^{27}$. Kontinuitas merupakan konsekuensi dari dinamika sosial yang memberikan jalan atas keberlanjutan suatu budaya. Dinamika juga membuka peluang atas konstruksi pendidikan konvergen, yakni pintu masuk atas mengglobalnya budaya lokal, suatu nilai adiluhung dengan sifat universal sebagai landasan atas kebaikan sosial melampaui batas-batas feodalisme pendidikan. Untuk melindungi identitas yang menunjukkan sifat kepribadian, sehingga tidak tergerus oleh globalisasi, maka dalam hal ini pendidikan memerlukan konsentrisitas, dengan cara berkaca kembali kepada nilai adiluhung yang secara asali diwariskan oleh nenek moyang Bangsa Indonesia. Artinya, pendidikan tentang geopolitik Indonesia setidaknya dapat mengakomodasi kebutuhan sekaligus tantangan globalisasi, tetap bervisi global namun tidak kehilangan indegenousitas kebangsaan Indonesia.

Hal pertama yang harus dipahami dalam pembacaan terhadap materi wawasan nusantara adalah dua konsep besar dalam doktrin kesatuan negara bangsa (nation-state) Indonesia, yakni "Bhinneka Tunggal Ika" dan "Tan Hana Dharma Mangrwa". Konsep pertama, "Bhinneka Tunggal Ika" merupakan nota kesatuan identitas kebangsaan yang tersusun dari keberagaman adat, budaya, dan kepercayaan sebagai pembentuk aspek ideologis, serta bentangan kepulauan dari Sabang sampai Merauke sebagai pembentuk pemahaman kewilayahan. Konsep kedua, yakni "Tan Hana Dharma Mangrwa"

Hidayatullah State Islamic University, 2015: 175-177)

27 Lihat Majelis Luhur Taman Siswa. Karya Ki Hadjar Dewantara Vol. IA Pendidikan (Yogyakarta: Majelis Luhur Taman Siswa, 1962: 206-207) 
merupakan kesatuan gagasan atas kebenaran bahwa identitas yang dimaksud adalah negara-bangsa yang disebut dengan Negara Kesatuan Republik Indonesia.

Pada aspek ideologis tersebut lah Islam dapat masuk dalam materi wawasan nusantara. Islam dalam diskursus ideologi bukan lah merupakan perwujudan tata ritual keagamaan yang tertutup, yang memiliki corak dan nafas yang berbeda dengan pandangan ritual keagamaan lain. Islam dalam pembahasan wawasan nusantara merupakan suatu eksistensi epistemologis yang memberikan sumbangsih pemikiran atas moral good warga negara untuk berpegang pada idegenousitas nasional. Meskipun nilainilai Islam merupakan hal yang bersifat global dan universal, dalam sejarah pemikirannya secara luas telah mempengaruhi tata kehidupan dan politik di nusantara, pra-Indonesia. Pada bagian tersebut lah PTKIN sebagai lembaga pendidikan tinggi dapat berperan secara aktif berinovasi, bahwa kajian studi Islam bukan merupakan bagian terpisah dari wawasan nusantara. Sepadan dengannya, Islam pada muaranya juga salah satu ideologi pengikat kesatuan negara-bangsa Indonesia, tanpa mengecilkan peran agama lainnya, dan dengan bersamaan dapat mengaktivasi setiap kebajikan dalam budaya lokal di masing-masing daerah.

Aspek kewilayahan, materi wawasan nusantara diarahkan pada doktrin pertahanan negara, meliputi materi geografis dan doktrin pertahanan negara. Sebagaimana amanat dari UUD 1945, pasal 30 tentang usaha pertahanan negara yang dilakukan secara terpadu. Sistem pertahanan dan Keamanan Rakyat Semesta (Sishankamrata) merupakan pelibatan kekuatan utama, Tentara Nasional Indonesia (TNI) dan Kepolisian Republik Indonesia, serta pelibatan kekuatan pendukung, yakni seluruh rakyat Indonesia. Keterpaduan antara materi geografis dan doktrin pertahanan negara, adalah keterpaduan kesadaran terhadap

${ }^{28}$ Armaidy Armawi, Strategi Pertahanan Nirmiliter dan Perguruan Tinggi, Jurnal Ketahanan Nasional, seluruh wilayah Indonesia dimanfaatkan secara utuh untuk pembinaan, pemanfaatan kepentingan nasional pertahanan, dan meleburnya kesadaran atas hak dan kewajiban warga negara atas bela negara dengan keyakinan pada kekuatannya sendiri. Selain membahas tentang materi kewilayahan kedaulatan negara, dalam hal ini juga disajikan letak strategis Indonesia di rangkaian bentang regional, termasuk di dalamnya langkah strategis politik yang dilakukan oleh negara dalam pergaulan internasional. Dengan demikian diharapkan adanya pemahaman warga negara atas kepentingan nasional dan kebutuhan hubungan internasional dan implikasinya terhadap kebijakan nasional.

Adapun tujuan dari pendidikan kewarganegaraan pada bagian materi geopolitik Indonesia ini adalah mempersiapkan warga negara sebagai kekuatan pertahanan non militer. Sishankamrata merupakan bagian strategis dalam upaya melestarikan kedaulatan bangsa. Hal tersebut sepadan apa yang disebut dengan pertahanan nirmiliter. Sebagaimana yang diungkap oleh Armaidy Armawi, bahwa pertahanan nirmiliter merupakan kekuatan pertahanan di luar militer itu sendiri. ${ }^{28}$ Bagaimanapun juga peserta didik di jenjang perguruan tinggi, terutama PTKIN merupakan bagian penting dari sistem pertahanan nasional, yakni kekuatan pendukung yang tidak dapat dinafikan perannya. Terlebih lagi sejarah telah mencatat, bahwa mahasiswa merupakan agen perubahan signifikan bagi peradaban sebuah negara.

\section{F. Penutup}

Globalisasi tidak selamanya mendefinisikan dunia tanpa batas (borderless). Krisis pandemi Covid-19 kembali membelenggu negara dalam batas-batas wilayahnya, bahkan dalam penanggulangannya dan mitigasi bencananya harus menutup akses pintu negaranya untuk orang asing secara fisik. Di sisi lain, banyak negara kesulitan sehingga membutuhkan uluran bantuan berupa utang negara dalam perspektif ekonomi, atau memaksimalkan

XI (3) Desember 2006, hlm. 33-40 (Yogyakarta: Jurnal Ketahanan Nasional, 2006:36) 
hubungan bilateral, regional, dan internasional (politik). Teori geopolitik tradisional sebenarnya telah memberikan clue atas mitigasi krisis global. Pemahaman tentang wilayah dan potensinya dengan didukung oleh kemandirian warga negara merupakan cara ampuh untuk mitigasi bencana apapun, baik perang maupun bencana alam. Meskipun tidak dapat dipungkiri, kemampuan hubungan internasional suatu negara juga turut andil dalam bertahan dalam situasi krisis.

Ancaman lain adalah laten hegemoni kekuasaan negara adikuasa, meskipun dalam setiap periode melibatkan aktor berbeda. Sebagaimana RRT menjadi penantang baru AS dalam upaya hegemoni ekonomi, politik, bahkan militer. Suka atau tidak, hal tersebut akan mempengaruhi posisi Indonesia di tengah tatanan dunia, pola hubungan internasional negara, hingga pengambilan kebijakan perdangangan, investasi ekonomi, maupun utang. Kompleksitas ancaman dipertajam oleh ketidakpastian situasi dalam negeri, secara tebal ditunjukkan oleh sikap primordialisme warga negara.

Pendidikan geopolitik Indonesia yang disesuaikan dengan kondisi wilayah dan ideologi bangsa sebagaimana yang disebut wawasan nusantara merupakan langkah preventif terbaik bagi keberdayaan warga negara dalam mitigasi krisis dan bencana. Terlebih di PTKIN, kekayaan intelektual Islam dapat dieksplorasi lebih sebagai alternatif-alternatif mumpuni strategi nasional yang dibingkai dalam identitas nasional sebagai pengikat rasa kebangsaan. Pancasila sebagai ideologi bangsa, merupakan ideologi terbuka yang mengadopsi segala moral good segala sumber pengetahuan dan nilai pembentuknya. Keberhasilan upaya keterpaduan cara pandang bangsa terhadap diri dan lingkungannya serta kesadaran atas nilai moral yang bersifat universal pembentuknya, akan membentuk karakter bangsa sebagai modal kuat bagi kemampuan pertahanan nirmiliter.

\section{G. Daftar Pustaka}

Anggoro, Kusnanto. 2017. Perubahan Geopolitik dan Ketahanan Nasional: Sebuah Penjelajahan Teoretikal, Jurnal: Kajian Lembaga Ketahanan Nasional Republik Indonesia Edisi 29 Maret 2017, hlm 5-16. Jakarta: Lembaga Ketahanan Nasional.

Armawi, Armaidy. 2006. Strategi Pertahanan Nirmiliter dan Perguruan Tinggi, Jurnal Ketahanan Nasional, Vol. XI No. 3 Desember 2006, hlm. 33-40. Yogyakarta: Universitas Gadjah Mada.

2009. Pengembangan Wawasan Nusantara Menuju Ketahanan Nasional, Jurnal Ketahanan Nasional Vol. XIV No. 3 Desember 2009, hlm. 113. Yogyakarta: Universitas Gadjah Mada.

Azra, Azyumardi. 2015. Civic Education at Public Islamic Higher Education (PTKIN) and Pesantren, Tarbiya: Journal of Education in Muslim Society Vol. 2 No. 2. Desember 2015, hlm 167177. Jakarta: Syarif Hidayatullah State Islamic University.

Direktorat Jenderal Pembelajaran dan Kemahasiswaan Kementerian Riset, Teknologi, dan Pendidikan Tinggi. 2016. Buku Ajar Mata Kuliah Wajib Umum: Pendidikan Kewarganegaraan. Jakarta: Dirjen Pembelajaran dan Kemahasiswaan Kemenristekdikti.

Efriani, et.al. 2019. Desain Kosmologi Sebagai Konservasi Alam Pada Komunitas Dayak Tamambaloh di Kalimantan Barat, Jurnal: An1mage Jurnal Studi Desain Vol. 2 No. 2, 2019 hlm. 66-74. Tangerang Selatan: AJSD.

Endraswara, Suwardi. 2013. Метауи Hayuning Bawana: Laku Menuju Keselamatan dan Kebahagiaan Hidup Orang Jawa. Yogyakarta: Penerbit NARASI.

Gökmen, Semra R. 2010. Geopolitics and The Study of International Relations. 
Ankara: Middle East of Technical University.

Grinin, Leonid dan Korotayev, Andrey. 2020. Covid-19 Pandemic, Geopolitics, and Recession, Kertas Kerja Ke-4: International Center for Education and Social and Humanitarian Studies. Moscow: Moscow State University.

Koentjaraningrat. 1974. Kebudayaan Mentalitet dan Pembangunan. Jakarta: Gramedia.

Majelis Luhur Taman Siswa. 1962. Karya Ki Hadjar Dewantara Vol. IA Pendidikan. Yogyakarta: Majelis Luhur Taman Siswa.

Ma'ruf dan Rasyid, A. 2019. Nilai-nilai Pendidikan Islam Dalam Tradisi Belalek. Pontianak: IAIN Pontianak.

Miska Amien, M. 2006. Causa Materialis Pancasila Menurut Notonegoro, Jurnal Filsafat Vol. 39 No. 1 April 2006, hlm 18-26. Yogyakarta: Fakultas Filsafat UGM.

Notonagoro, Pancasila Secara Ilmiah Populer. Jakarta: Pantjuran Tudjuh.

Sudira, Putu. 2014. Konsep dan Praksis Pendidikan Hindu Berbasis Tri Hita Karana. Makalah Seminar Eksistensi Pendidikan Hindu dalam Sisdiknas di Era Global. Yogyakarta: Universitas Negeri Yogyakarta.

Sulisworo, T. Dwi, et al. 2005. Bahan Ajar: Geopolitik Indonesia. Yogyakarta: Universitas Ahmad Dahlan.

The Warsawa Institute Review. 2020. Great Power Politics in The Post Covid-19, Artikel diupload 6 April 2020, diakses dari https://warsawinstitute.review/new s-en/great-power-politics-in-thepost-, pada 26 Juni 2020.
Torkanovskiy, E.P. 2019. In Defence of Autarky as a Modern Way of National Economic Development, Journal of International Economic Affairs Vol. 9 No. 1, Maret 2019, hlm. 157-168. Moskow: Journal of International Economic Affairs.

Sukardi. 2005. Metodologi Penelitian Pendidikan. Jakarta: PT Bumi Aksara.

Smith and Robbinson. 1980. Reading Instruction for Today's Children. New Jersey: Englewood Cliffs.

Wallace, Michael J. 1988. Action Research For Language Teachers. Cambridge: Cambridge University Press.

William, Eddie. 1999. Reading in the Language Classroom. London: Phoenix FLT.

http://apt.rcpsych.org/cgi/reprint/5/5/376.pdf http://diffundo.com/instructions/resource15. pdf

http://lds.org/paprimary/program/CSMP_20 07_\%20Files/tngcPages161_162.pdf http://www.cte.umd.edu/library/folio.pdf http://faculty.ksu.edu.sa/7338/pdf/993.pdf http://www.ilo.org/public/english/employme nt/recon/eiip/download/train_toolbox.pdf http://amec.glp.net/c/document library/get f ile?p_1_id=844086\&folderId=1077184\&na $\underline{\mathrm{me}=\text { DLFE}-20788 . \mathrm{pdf}}$

http://bible.org/seriespage/using -buzzgroups- your-teaching.pdf

(file:///G:/reading/Approaches\%20to\%20Readin g.htm)

Sukardi. 2005. Metodologi Penelitian Pendidikan. Jakarta: PT Bumi Aksara.

Smith and Robbinson. 1980. Reading Instruction for Today's Children. New Jersey: Englewood Cliffs.

Wallace, Michael J. 1988. Action Research For Language Teachers. Cambridge: Cambridge University Press.

William, Eddie. 1999. Reading in the Language Classroom. London: Phoenix FLT. 
http://apt.rcpsych.org/cgi/reprint/5/5/376 .pdf

http://diffundo.com/instructions/resource 15.pdf

http://lds.org/paprimary/program/CSMP _2007_\%20Files/tngcPages161_162.pd $\mathrm{f}$

http://www.cte.umd.edu/library/folio.pdf http://faculty.ksu.edu.sa/7338/pdf/993.pdf http://www.ilo.org/public/english/emplo yment/recon/eiip/download/train_toolb ox.pdf

http://amec.glp.net/c/document_library/g et_file?p_1_id=844086\&folderId=1077 184\&name=DLFE-20788.pdf

http://bible.org/seriespage/using -buzzgroups- your-teaching.pdf

(file:///G:/reading/Approaches\%20to\%20Re ading.htm) 